DOI: 10.20472/IAC.2018.036.004

\author{
MUHAMMAD BILAL \\ Fatima Jinnah Women Univeristy, Pakistan
}

\title{
RETHINKING THE AUTHORITY OF 'ULAMAA' AND MOSQUES IN SHAPING RELIGIOUS DISCOURSE IN PAKISTAN: AN ETHNOGRAPHIC ACCOUNT
}

\begin{abstract}
:
The mosque (masjid; plural masaajid) is the fundamental institution in any Islamic society, its role extending far beyond its function as a religious centre. The question that arises for this ethnographic study in Pakistan is whether the masjid is still as central as it was in the past, or as it is understood to be. A similar question can be raised for those 'ulamaa' (Muslim scholars trained in Islamic law; singular 'aalim) who frequent the mosque and serve the religious community as imaam masajid (prayer leaders) . This study finally explores the part played by the masjid - and by the 'ulamaa' - in the life of worship and, beyond that, in the everyday social structure. The study suggests that no longer can the 'ulamaa' or masaajid be called representative of Pakistani society.
\end{abstract}

\section{Keywords:}

'ulamaa', Mosque, Islam, Pakistan, culture 